Poznańskie Studia Teologiczne 30(2016), s. 93-103.

doi: $10.14746 /$ pst.2016.30.03

\author{
Andrzej Andrewald ${ }^{1}$ \\ Uniwersytet Opolski \\ Wydział Teologiczny
}

\title{
The Credibility of Faith and Paranormal Phenomena
}

If the Church is not to be accused of being deaf to people's longings - we read in the Document of Pontifical Council for Culture and Pontifical Council for Interreligious Dialogue Jesus Christ the bearer of the water of life - her members need to do two things: to root themselves ever more firmly in the fundamentals of their faith, and to understand the often-silent cry in people's hearts, which leads them elsewhere if they are not satisfied by the Church $^{2}$.

In the present day, when the vision of our world is dominated by the natural sciences and technology, the interest in paranormal phenomena seems to be one such silent cry of the modern man. Even a cursory look at a search results list in Google databases points at the keen interest taken in issues surrounding the paranormal and the extraordinary phenomena. A search for information on the issues is nothing short of encountering a deluge of data. Internet databases return about 3610000 reference links to the entry "paranormal phenomena" in English and 431000 in Polish alone ${ }^{3}$. A further narrowing down of search results by cross-referencing the terms "faith" and "paranormal phenomena" returned 243000 links in English and 85300 in Polish respectively. A further down-pinning of the term "faith" to "Christian faith" in connection to "paranormal phenomena" produced 26000 search results in English 155000 and 25500 in Polish .

The growing interest in paranormal phenomena is quite commonly associated, on the one hand, with a reaction to rational one-sidedness, a "technical and scientific" world view and the condition of a man who cannot answer the funda-

\footnotetext{
${ }^{1}$ Rev. Andrzej Anderwald, associate professor of fundamental theology and science of religion at University of Opole (Poland). He is particularly interested in the relationship between faith and reason, theology and natural science, and the proper role of scientific thinking in theology.

${ }^{2}$ Pontifical Council for Culture and Pontifical Council for Interreligious Dialogue, Jesus Christ the bearer of the water of life. A Christian reflection on the "New Age" (2003), section $1.5 \mathrm{http}: / /$ www.vatican.va/roman_curia/pontifical_councils/interelg/documents/rc_pc_interelg_doc_20030203 _new-age_en.html [access: 24.05.2016].

${ }^{3}$ See www.google.pl (search for the term: ,paranormal phenomena”) [access: 20.05.2016].

${ }^{4}$ See www.google.pl (search for the terms: ,faith and paranormal phenomena” and ,christian faith and paranormal phenomena" [access: 20.05.2016].
} 
mental questions of human existence, and who often a priori denies the existence of a transcendent reality. On the other hand, questioning or rejection of the Christian faith - and dismissing it as irrational behaviour - has created in many a spiritual void that makes for a fertile ground for the emergence of new religious movements like New Age and the adoption of a new esoteric religiosity that are open to paranormal phenomena ${ }^{5}$.

In this discussion we will attempt to answer the questions which are implied by the problem contained in the title: What - in general - can be the relationship between the Christain faith and paranormal phenomena? Can paranormal phenomena be attributed to a function in an act of faith? What are the differences between paranormal phenomena and the understanding of miracle in Christian theology? In this study, paranormal phenomena are investigated on the background themes of the credibility of Christian faith. The whole discussion involves three stages: (1) characterization of paranormal phenomena, (2) clarification of the motives of the Christian faith and their verification as illustrated by an example of a miracle, and (3) presentation and analysis of challenges from the side of paranormal phenomena for the credibility of Christian faith.

\section{Paranormal phenomena: outside of scientific evidence}

How can paranormal phenomena be characterized? What does the term imply? As was already pointed out in the introduction, the multiplicity of issues relating to "paranormal phenomena" - as well as their diversity - does not allow for a single perspective that would meet with universal approval. It is worth noting that the term is a rare occurrence in Polish lexicographical studies. It is, however, included in the Brockhaus Encyclopaedia, where the expression "paranormal phenomena" is understood as incidents of extrasensory perception and psychokinesis that defy scientific explanation ${ }^{6}$. A more descriptive approach to the term "paranormal phenomena" may be found in Lynn Piknett's pop-science Encyclopaedia of the Paranormal ${ }^{7}$. The Encyclopaedia emphasizes dissimilarity between the paranormal and the esoteric, the latter of which is classified as belonging to the domain of the occult. Furthermore, paranormal phenomena are defined as those which the classical science cannot - or will not - examine nor account for, and as such they occur independently of the laws of nature ${ }^{8}$.

Hence paranormal phenomena are those occurrences that are unexplainable along the lines of science and beyond the grasp of methods implemented in the

${ }^{5}$ See D. Heeg, Ein enormer Bedarf. Nächtliche Astro-Sendungen im deutschen Privatfernsehen, "Herrder Korrespondenz" 60(2006) No. 10, p. 510-513.

${ }^{6}$ Paranormale Phänomene, in: Brockhaus Enzyklopädie, vol. 16, Mannheim 199920, p. 527.

${ }^{7}$ L. Picknett, Encyklopedia zjawisk paranormalnych, tłum. J. Prokopiuk, Warszawa 1993.

${ }^{8}$ Ibid, p. 11. 
natural sciences, and empirical investigation in particular. They occur as singularities and are diversified. What then are these phenomena? In keeping with the subject matter of our discussion we shall limit ourselves to a description of paranormal phenomena that is associated with religious themes and has not infrequently been utilized in efforts to explain occurrences of religious nature ${ }^{9}$. Referrences to "paranormal phenomena" usually imply such occurences as: (1) hypnosis (Gk. ipnos - meaning 'open', 'sleep') is a state of human consciousness involving focused attention and reduced peripheral awareness and an enhanced capacity for response to suggestion; (2) telepathy (Gk. tele meaning 'distant' and pathos or patheia meaning 'feeling', 'perception', 'passion') is the purported transmission of information from one person to another without using any of our known sensory channels or physical interaction; the transference of thoughts or feelings between two or more subjects through psi as the unknown factor in the extrasensory perception; (3) clairvoyance - the ability to gain information about an object, person, location or physical event through means other than the known senses; (4) extrasensory perception or ESP, also called sixth sense, includes reception of information not gained through the recognized physical senses but sensed with the mind; (5) psychokinesis (Gk. psyche 'mind' and kinesis 'movement'), or telekinesis (from tele 'far off' and kinesis 'movement'), is an alleged psychic ability allowing a person to influence a physical system without physical interaction; (6) levitation (Latin levitas 'lightness') is the process by which an object is held aloft, without mechanical support, in a stable position; in the paranormal context is the rising of a human body into the air by mystical means ${ }^{10}$.

The futility of efforts to find a common denominator for the listed phenomena proves them to be particularly difficult to research. As underscored by contemporary parapsychology there is in fact no analytical method that would allow for an investigation of the phenomena. There is not a single record of a reliable experiment that would prove any such phenomenon as fact. Parapsychology may be known for its attempts to inspect the phenomena, nevertheless it has no immediate access to them nor does it have adequate research tools. While the fact does not disprove the existence of paranormal phenomena as such, it does point at the impossibility of accounting for their nature and origin ${ }^{11}$. Psychic abilities of some people are the most commonly quoted source of the phenomena. A clairvoyant or a psychic may claim to possess extraordinary skills or abilities, however in light of parapsychology these cannot be subjected to an analysis that would incorporate methods applied in academic psychology. Due to lack of sci-

\footnotetext{
${ }^{9}$ See M. Rusecki, Teologia wobec zjawisk paranormalnych, Częstochowa 2010, p. 9-32.

${ }^{10}$ See for example: A. Nowak, Parapsychologia, Lublin 2006, p. 54-61; S. Pile, Distant feelings: telepathy and the problem of affect transfer over distance, "Transactions of the Institute of British Geographers" 37(2012) No. 1, p. 44-59.

${ }^{11}$ A. Nowak, Parapsychologia, op. cit., p. 65-67.
} 
entific explanation these phenomena are classified as belonging to the field of pseudoscience (parascience).

But are other, non-scientific, efforts made to explain paranormal phenomena? Source literature provides three alteranative models of explaining paranormal phenomena. Currently the most common model, one that stands in opposition to the Christian faith, is occultism (Latin occultus - 'hidden', 'concealed'; 'knowledge of the hidden' - scientia occulta). Even though there are numerous meanings attributed to the term ${ }^{12}$, it is meant here in reference to esoteric doctrines based on the assumption that there are in man and in nature secret and unknown powers whose existence cannot be proven by means and in the process of rational cognition.

Another approach to explaining paranormal phenomena - one that in turn stands in opposition to occultism - is total scepticism, which seriously questions the existence of the paranormal. A yet another model for expounding on paranormal phenomena, propagated in Christian fundamentalist milieux, sees their origin in the activity of evil spirits or demonic powers. Supporters of this model maintain a negative stance to the various Christian initiatives whose aim is to promote openness to new forms of spirituality and religion, like the prayer meetings in Assisi, the problem of esoteric religiousness, or more particurarly homeopathy and occultism ${ }^{13}$.

What, then, is the relation between the Christian faith and the issues relating to paranormal phenomena? Does the secular - or even lay - societies' growing interest in the paranormal offer an evangelizing opportunity for the Church in terms of the patristic praeparatio evangelica? Yet before we provide a straightforward answer to the questions posed above, we need to address the issue of motives that underlie the credibility of the Christian faith.

\section{Motives for faith: miracles vs. paranormal phenomena}

In the Catechism of the Catholic Church we read:

What moves us to believe is not the fact that revealed truths appear as true and intelligible in the light of our natural reason: we believe "because of the authority of God himself who reveals them, who can neither deceive nor be deceived." So "that the submission of our faith might nevertheless be in accordance with reason, God willed that external proofs of his Revelation should be joined to the internal helps of the Holy Spirit." Thus the miracles of Christ and the saints, prophecies, the Church's

${ }^{12}$ See A. Posacki, Niebezpieczeństwa okultyzmu, Kraków 2010; A. Posacki, Ezoteryzm i okultyzm - formy dawne i nowe: aspekty filozoficzno-teologiczne i praktyczno-duszpasterskie, Radom 2009.

${ }^{13}$ See H.J. Ruppert, Der christliche Glaube und das Paranormale, p. 18 (pdf. www.ezwberlin.de) [access: 15.05.2016]. 
growth and holiness, and her fruitfulness and stability "are the most certain signs of divine Revelation, adapted to the intelligence of all;" they are "motives of credibility" (motiva credibilitatis), which show that the assent of faith is "by no means a blind impulse of the mind" (No. 156).

This passage from the Catechism points at the significance of arguments of reason in an act of faith. In Christianity an act of faith is understood as an interpersonal relationship, where man's trust in God is based on the testimony by means of which God reveals himself to man. Faith is understood as man's response to God, who comes to meet him - the divine Revelation. Faith is, then, man's response to God's call. The key role in the genesis of faith is played by the motives of credibility such as miracles, someone's witness of life, someone's holiness, and charity. Once the decision of faith has been taken these motives become the motives of faith. They are personal in character, because their credibility is based on God's personal witness. The argument from miracles may also be counted as one of the motives. From the theological point of view that is expressed in this discussion, however, it would be a mistake to consider a miracle on a par with an extraordinary occurrence of the paranormal type. Theology understands miracles as signs of God working in the world for the salvation of man. Miraculous occurrences are God's acts of self-revelation in history and signify his salvific works that were fully revealed in the person of Jesus Christ ${ }^{14}$.

The proper process of recognizing a miracle as a sign from God requires two types of recognition: scientific and religious. The scientific inverstigation focuses only on the phenomenological, empirical aspect of a miracle, with the aim of recognizing a transcendent character of the extraordinary occurrence, by which is not meant a comprehensive and definitive recognition of the occurrence as a miracle, but that of merely one element of the phenomenon. The scientific process of recognition of a miracle is marked by the participation of the auxiliary sciences of history, exact (various branches of medicine, psychology and natural sciences), and philosophical and theological sciences ${ }^{15}$. Their role is one of establishing as fact an occurrence purported to be extraordinary, obtaining proof of the existence of a transcendent cause of a miraculous event based on the priciples of causality and sufficient reason, and demonstrating the possibility of a permanent connection between the extraordinary occurrence and the religious context.

The complete process of recognizing a miracle also involves an inquiry of religious nature, as it cannot be exhausted by the scientific analysis (including the theological one) and demands for a complementary one in the form of reli-

${ }^{14}$ A.O. Søvik, Why Christian Theology Should Accept that Miracles Occur, "Science \& Christian Belief', 22(2010) No. 2, p. 161-162.

${ }^{15}$ S. Horst, Miracles and two accounts of scientific laws, "Zygon" 49(2014) No. 2, p. 326-331. 
gious recognition that is synthetic in character. A religious investigation of a miracle requires of man - besides the general knowledge about the nature of the world (the critical mind) - a moral condition, that is to say, good will and openness to supernatural reality. Religious inquiry yields the result of moral certainty, which constitutes the highest level of certainty that can be attained on the religious plane. Certainty of this kind is the outcome not only of a mental effort, since it is the fruit of the commitment of man as a whole, and forms in him a solid ground for openness to the supernatural reality that has been recognized in a miraculous event ${ }^{16}$.

The motivational aspect of the process of recognizing a miracle we just presented, however, is no basis to consider it as equivalent to an extraordinary event of the paranormal type (though such erroneous reduction has been made and still occurs occasionally). The very nature of paranormal phemomena that stands in radical contrast to that of miraculous occurrences, and the lack of uniform and reliable methods of verifying the former - against the background of the nature and function of miracle in theology - do not allow to assess the paranormal in terms of rational motives for faith. Yet the fact being that paranormal phenomena cannot be numbered among the motives of the Christian faith, do they remain completely neutral to how a person's faith is formed? Do they have any impact on one's faith? Can the way they relate to the Christian faith be unambiguously determined? An attempt to address these questions is the focus of the concluding remarks in our discussion.

\section{Paranormal phenomena: a call for the Christian faith}

From the very beginnings of Christianity upholding the belief in one God required constant purification of his image both within the cult itself and in everyday practice of the faith. And in accordance with the call from the First Letter of Peter the Apostle: "Always be ready to give an explanation to anyone who asks you for a reason for your hope" (1 P 3:15), the Church nowadays has to cope not only with the negation of God and adamant atheism or agnosticism, but also with a new and attractive culture of spirituality whose content cannot be reconciled with the divine revelation. Therefore the interest in paranormal phenomena on the part of Christian theology should consist in critical appraisal, especially in cases where by taking recourse to them attempts are made to explain redemptive events or altogether equate them with the miracles recounted in the Bible.

Jesus Christ the bearer of the water of life. A Christian reflection on the "New Age" comprises a reliable resource on which to make an assessment from

${ }^{16}$ See A. Anderwald, Rozpoznanie cudu, in: Leksykon teologii fundamentalnej, ed. M. Rusecki, K. Kaucha, I.S. Ledwoń, J. Mastej, Lublin 2002, p. 1043-1044. 
the Church's perspective in our discussion. Published in 2003, it was a concerted effort undertaken by the Pontifical Council for Culture and Pontifical Council for Interreligious Dialogue. Although the document does not mention paranormal phenomena explicitly, its main focus being the new spirituality of the New Age movement and how it differs from Christianity, the recommendations formulated within the publication are significant in the context of paranormal phenomena, as they comprise a key element of the new spirituality.

Interest in paranormal phenomena and the element of belief it involves stands in stark opposition to the meaning of revealed Christian faith, and hence cannot be considered as harmless. In a culture marked by pluralization and religious relativism one should advise against attempts to treat esoteric religiousness that comprises the element of paranormal phenomena and the Christian faith as equal. People should be made aware that it is not possible to believe both in redemptive events (like miracles, prophecies and resurrection) and paranormal phenomena. For a Christian it is an "either-or" option: "No servant can be the slave of two masters: he will either hate the first and love the second, or treat the first with respect and the second with scorn" (Lk 16:13). "Christians - we read in the Document - have only to think of the difference between the wise men from the East and King Herod to recognize the powerful effects of choice for or against Christ. It must never be forgotten that many of the movements which have fed the New Age are explicitly anti-Christian" ${ }^{17}$. And this means specifically that believing in miracles as signs of God's revelation and believing in paranormal phenomena cannot be reconciled. Furthermore, active interest often takes the form of employing various practices (e.g. visiting fortune-tellers, participating in seances) that are motivated by the desire to know the future. Such attitude may be interpreted as a way of expressing the belief that some impersonal and mysterious energy can interfere in the reality of human life. This kind of belief can in turn lead to a kind of "re-mythologization" of reality. Adherence to such belief in the context of human actions may lead man to renounce the responsibility for his own life ${ }^{18}$. The Christian faith, however, is a personal act that involves a person's commitment on all levels and demands to be lived out.

Similarly, focusing on a given paranormal phenomenon itself or on the experience thereof should be assessed critically. What is fundamental to the Christian faith, namely relationship with God understood as meeting and dialogue, is lacking in encounter with a paranormal phenomenon. The peculiarity of belief in paranormal phenomena finds its expression in monologue, where the relationship

${ }^{17}$ Pontifical Council for Culture and Pontifical Council for Interreligious Dialogue, Jesus Christ the bearer of the water of life, section 6.1.

${ }^{18}$ See M. Machinek, Homo esotericus. Uwagi na marginesie raportu Papieskiej Rady Kultury “Jezus Chrystus dawca wody żywej”, in: Ocalić obraz człowieka. Antropologiczne podstawy moralności, ed. P. Morciniec, Opole 2003, p. 146. 
between the human "I" with the divine "you" is substituted with a scheme in which the human "I" relates to a divine "it", an apersonal power that permeates all, including the human nature. Focusing on personal experience alone leads to rejection of religious authority. The intensity of a person's inner experience becomes the sole criterion for a religion's authenticity. This in turn may often generate motivation to fall back on pre-Christian religions which are perceived as possessing a pure element of experience at their core, and which are unadulterated by any distinctive and extensive doctrine. In such case the method of "finding the truth" is governed by positive emotions and experiences. And for that reason it is then no longer relevant whether one can get closer to the truth, the top priority being given to reaching a state of psychological and spiritual bliss. A religion's main proposition does not have to be valid - its principal role consisting in its potential usefulness in terms of meeting an individaul's needs and expectations. In this context "spirituality" is defined as an inner experience of harmony and oneness with reality as a whole, an experience that supposedly heals people of their sense of imperfection and finiteness. They then discover a personal connection with a universal power or life-force ${ }^{19}$. This act of opening to apersonal powers (energies) - seen as a potential form of channeling, a way of establishing a channel of communication with the supernatural - is characteristic of paranormal phenomena (like levitation, telekinesis or spiritism) and poses a threat to a personal and dialogic nature of the Christian faith, as well as to the rational dimention of an act of faith.

Credibility of Christian faith is threatened by attempts to seek any recourse in the nature of paranormal phenomena in order to explain religious events (like revelations, theophanies, prophecies, miracles or even the resurrection of Christ). Such efforts were made in the past by specialists in marxist religious studies with the aim of deprecating Christian redemptive events ${ }^{20}$.

It is also worth noting here that investigating the context of paranormal phenomena is important for the credibility of Christian faith. The aim of this type of research is to avoid putting hasty religious interpretations on all paranormal phenomena that are experienced by people in their every-day lives (like telepathy or telekinesis) and which defy common sense and are an "insult to human reason". And although such experiences transcend the common experience of reality, it does not mean they have something to do with religious belief or religious transcendence.

Considering all the critical remarks, one cannot help but notice the threats that interest in paranormal phenomena poses to the Christian faith. Hence apologetic attitude in encountering paranormal phenomena is entirely justified. And as we read in the document of the Pontifical Councils, "Even if it can be admitted that New

\footnotetext{
${ }^{19}$ See Pontifical Council for Culture and Pontifical Council for Interreligious Dialogue, Jesus Christ the bearer of the water of life, sections 3.1 and 3.2.

${ }^{20}$ See M. Rusecki, Teologia wobec zjawisk paranormalnych, p. 9-30.
} 
Age religiosity in some way responds to the legitimate spiritual longing of human nature, it must be acknowledged that its attempts to do so run counter to Christian revelation" ${ }^{21}$. Does this imply outright rejection of paranormal phenomena in the study of theology? Can interest in paranormal phenomena be perceived as a sign of the times and a challenge to the Christian faith, the Church and its theology?

As indicated in Councils' reflection on New Age, there are some areas where interest in paranormal phenomena may represent challenges to the faith. One of these areas can be defined as a genuine yearning "for a deeper spirituality, for something which will touch their hearts, and for a way of making sense of a confusing and often alienating world" 22 . This yearning, along with the resultant openness to paranormal phenomena go hand in hand with a negative attitude towards materialisation of everyday life and the deprecation - or outright negation - of religious and supernatural experiences. The mere interest in paranormal phenomena reveals spiritual longing in man, and the resultant desire to satisfy it. This very yearning is a call for discovering in Christianity such forms of spirituality and piety that would engage man as a whole. In this case it seems a matter of general importance that Christian communities gave man's non-material needs a more thoughtful consideration. This would also imply a need for a greater appreciation of the depth of Christians' religious experiences, and their spiritual and mystical life. Initiating more vigorous efforts in terms of positive action in Christian communities may contribute to garnering attention to the beauty and depth in the experience of Christian faith. The oft-repeated words John Paul II - in the context of the Church's journey in the third millennium - "put out into the deep" (duc in altum - Lk 5:4) $)^{23}$ - map out the tasks and point out an appropriate attitude Christians should cultivate in the encounter with mentality and spirituality inspired by paranormal phenomena.

In an interview about the need for a new Christian spirituality, Gotthard Fuchs, a theologian, calls for a more direct expression of the yearning for God and his promises - in Christianity. Responding to this call would involve: (1) overcoming all divisions between the Gospel and culture, and between the dialect of the Church and the language of the world; (2) removing impediments in communication between theology and spirituality; and (3) presenting celebration of sacramental mysteries (like that of Sunday Eucharist) as spaces for Christian mysti$\operatorname{cism}^{24}$.

${ }^{21}$ Pontifical Council for Culture and Pontifical Council for Interreligious Dialogue, Jesus Christ the bearer of the water of life, section 1.4.

${ }^{22} \mathrm{Ibid}$, section 1.5 .

${ }^{23}$ Jan Paweł II, Apostolic letter Novo millennio ineunte (2001), https://w2.vatican.va/content/ john-paul-ii/pl/apost_letters/2001/documents/hf_jp-ii_apl_20010106_novo-millennio-ineunte.html [access: 20.06.2016]. No. 1.

${ }^{24}$ See Neuer Bedarf an Spiritualität. Ein Gespräch mit dem Theologen Gotthard Fuchs, "Herrder Korrespondenz" 59(2005) No. 9, p. 450-451. 
$* * *$

In conclusion, we may say that there is no basis whatsoever that would allow for an assessment of paranormal phenomena in terms of their nature, nor is is possible to verify them by carrying out a scientific and/or religious investigation along the lines of the credibility of Christaian faith. The proper process of recognizing a miracle as a sign from God, its motivational function in the act of faith, is no basis to consider it as equivalent to an extraordinary event of the paranormal type. It may be admitted, though, that paranormal phenomena do generate openness to a heightened perception of reality which in principle is free of naturalist reductionism. It should be noted, however, that in many cases people's fascination with a heightened perception of reality does not lead to a religious experience, but takes the form of an alternative religion with the aim of replacing the traditional belief system with a universal spirituality and a heightened perception. Therefore considering the relationship between paranormal phenomena and the Christian faith in a broad perspective, one cannot simply restrict an assessment of it to critique alone. In point of fact, it seems that another analysis is necessary; one that would reveal the very motives behind the interest with such phenomena. This in turn would allow to better diagnose the spiritual longings and desires of the contemporary man.

\section{The Credibility of Faith and Paranormal Phenomena}

\section{Summary}

The aim of those deliberation is focused on answering the questions: Can paranormal phenomena be attributed to a function in an act of faith? In this study paranormal phenomena are investigated on the background themes of the credibility of Christian faith. The whole discussion involves three stages: characterization of paranormal phenomena (1), clarification of the motives of the Christian faith and their verification of the example of a miracle (2), as well as presentation along with analysis challenges from the side of paranormal phenomena for the credibility of Christian faith (3).

\section{Keywords}

The Christian faith, credibility, paranormal phenomena

\section{Wiarygodność wiary a zjawiska paranormalne}

\section{Streszczenie}

Celem podjętych rozważań jest próba udzielenia odpowiedzi na pytania: Czy można zjawiskom paranormalnym przypisać jakąś funkcję w akcie wiary? Zjawiska te zostaną poddane analizie na tle zagadnienia motywów wiary chrześcijańskiej. Całość rozważań obejmuje trzy etapy: najpierw zostanie przedstawiona charakterystyka zjawisk paranormalnych (1); następnie motywów 
wiary i ich weryfikacji na przykładzie cudu (2); oraz wskaże się na wyzwania jakie dla wiary chrześcijańskiej stanowią zjawiska paranormalne (3).

\section{Słowa kluczowe}

wiara chrześcijańska, wiarygodność, zjawiska paranormalne

\section{Bibliografia}

Anderwald A., Rozpoznanie cudu, in: Leksykon teologii fundamentalnej, ed. M. Rusecki, K. Kaucha, I.S. Ledwoń, J. Mastej, Lublin 2002, p. 1043-1044.

Heeg D., Ein enormer Bedarf. Nächtliche Astro-Sendungen im deutschen Privatfernsehen, "Herrder Korrespondenz" 60(2006) No. 10, p. 510-513.

Horst S., Miracles and two accounts of scientific laws, "Zygon" 49(2014) No. 2, p. 323-347.

Jan Paweł II, Apostolic letter Novo millennio ineunte (2001) https://w2.vatican.va/content/ john-paul-ii/pl/apost_letters/2001/documents/hf_jp-ii_apl_20010106_novo-millennioineunte.html [access: 20.06.2016].

Machinek M., Homo esotericus. Uwagi na marginesie raportu Papieskiej Rady Kultury “Jezus Chrystus dawca wody żywej”, in: Ocalić obraz człowieka. Antropologiczne podstawy moralności, ed. P. Morciniec, Opole 2003, p. 139-148.

Neuer Bedarf an Spiritualität. Ein Gespräch mit dem Theologen Gotthard Fuchs, Herrder Korrespondenz" 59(2005) No. 9, p. 447-452.

Nowak A., Parapsychologia, Lublin 2006.

Paranormale Phänomene, in: Brockhaus Enzyklopädie, vol. 16, Mannheim 1999²0, p. 527.

Picknett L., Encyklopedia zjawisk paranormalnych, thum. J. Prokopiuk, Warszawa 1993.

Pile S., Distant feelings: telepathy and the problem of affect transfer over distance, "Transactions of the Institute of British Geographers" 37(2012), No. 1, p. 44-59.

Pontifical Council for Culture and Pontifical Council for Interreligious Dialogue, Jesus Christ the bearer of the water of life. A Christian reflection on the "New Age" (2003).

Posacki A., Niebezpieczeństwa okultyzmu, Kraków 2010.

Posacki A., Ezoteryzm i okultyzm - formy dawne i nowe: aspekty filozoficzno-teologiczne i praktyczno-duszpasterskie, Radom 2009.

Rusecki M., Teologia wobec zjawisk paranormalnych, Częstochowa 2010.

Ruppert H.J., Der christliche Glaube und das Paranormale, (pdf. www.ezw-berlin.de) [access: 15.05.2016].

Søvik A.O., Why Christian Theology Should Accept that Miracles Occur, "Science \& Christian Belief' 22(2010) No. 2, p. 151-165. 